\title{
Marimekko triibusärgi (Tasaraita) fenomen ${ }^{1}$
}

\begin{abstract}
Arja Turunen
Teesid: Artiklis vaadeldakse Soome klassikaks kujunenud Marimekko ajalugu ja Tasaraita kaubamärgi all turustatava triibusärgi fenomeni. Algul tähendas Marimekko elitaarseid disainrõivaid, hiljem noorterõivaid ja lõpuks sai sellest Tasaraita kaudu kogu rahva mood. Marimekko disaini põhimõtted esindavad oma aega ehk 1950. aastate ajatut ja lihtsat tootekujundusfilosoofiat multifunktsionaalsust. Pidu- ja argirõivaid ei kujundatud enam eraldi toodetena. Eesmärgiks oli rõivastada kogu rahvas, kuid ettevõtte tarbijaskonna moodustasid valdavalt haritud ja jõukad linnaelanikud.

1960. aastatest hakati üha sagedamini ostma kauplustest valmisrõivaid. Annika Rimala jõudis Tasaraita tootemärgi loomiseni 1968. aastal. Tema eesmärk oli kujundada multifunktsionaalne trikoopluus, mida võivad kanda kõik imikutest vanuriteni - kujunduskontseptsioonis sisaldus selgesti maoistlik võrdsustamisideoloogia. Võrdõiguslikkusmõtte haripunktiks võib pidada 1970. aastate alguses kasutusele võetud unisex-moodi. Tüüpilist unisex-moodi esindas teksadest ja T-särgist koosnev rõivastus. Nagu teksad, nii on ka Tasaraita muutunud ühe ajajärgu uudsest või isegi mässavast rõivastusest mitmetel puhkudel kantavaks üldrõivaks.
\end{abstract}

Märksõnad: demokraatia, Marimekko, moefilosoofia, noorterõivad, rõivakujundus, rõivastumisstiil, Soome klassika, sotsiaalne võrdsus, Tasaraita

\section{Klassikaline rõivastus ja moe ringkäik}

Kui moeuurija Kaj Kalin (Niskanen 2003: 6) püüdis mõistatada, millised tänapäevased asjad võivad tulevikus muutuda antikvaarsusteks, mainis ta ühe näitena Marimekko triibusärki, st Tasaraita-kaubamärgi all toodetavat trikoosärki. Valik ei ole üllatav, sest Tasaraita on kujunenud soome disainiklassikaks: see on jäädvustatud soome moodi tutvustavas postmargisarjas ja seda on nimetatud nii rahvuslikuks omandiks kui ka soome uueks rahvarõivaks. ${ }^{2}$ Tähelepanuväärne on kõnealuses ajalehekirjutises see, kuidas K. Kalin põhjendab oletust Marimekko Tasaraita-toodangu "antikvaarsuseks" saamisest. 
Ta pidas määratlemisel märkimisväärseimaks ja olulisimaks toodetega kaasnevaid lugusid, nn elegantsilegende. Nendest kirjeldab ta näiteks Tasaraitaga seotut:

Jacqueline Onassis [Kennedy] kandis neid peamiste riietusesemetena ajakirjas Life ilmunud loo illustratsioonidel, millest see [kaubamärk] sai üha kasvava prestiižse maine ${ }^{3}$ (Niskanen 2003: 6).

K. Kalin loos toodud näide on üks triibusärgiga kaasnev legend, mis pole kaugeltki ainus. Enam kui 35-aastase tegutsemisaja jooksul on Tasaraitast saanud rõivamärk, mis on selgesti ütelnud lahti loojast ja asunud elama iseseisvat elu (Saarela 2000: 5). Oma kirjutises vaatlen seda Tasaraita olemust neid tähendusi, mis teevad triibusärgist soomlaste rõivastuse fenomeni.

Tasaraita klassikapositsioonile viidates vaatlen üldiselt tema tähendusest vähemuutuva ja ajatu soome moe esindajana - on ju samu üsna lihtsaid rõivamudeleid müüdud ühtejärge enam kui 35 aastat. Tasaraita puhul on küsimus ka Marimekko disainis, mis on olnud soomlastele kvaliteedi tagatis juba 1950. aastatest alates. Tasaraita menu ongi näide õnnestunust moest ja Marimekko menu vastavalt näide moe tähendusest rõivastuse kavandamisel. Panustamine tootekujundusse ei taga ettevõttele ja selle toodangule siiski automaatselt menu. Disaintoodangut valmistava ettevõtte majanduskasumi moodustumist uurinud Antti Ainamo (1996) järgi mõjutavad ettevõtte tulusid ka äritehingutega kaasnevad tegurid. Nende kaasnevate tegurite all mõtleb ta sotsiaalset tellimust ja ettevõttesisest kommunikatsiooni ehk võimet muuta ideed toodeteks.

A. Ainamo käsitleb näitena Marimekko Oy-d ja näitab majandusperioodide kaupa, et ettevõtte tootekujunduse tase ei korreleeru alati ettevõtte majanduskasumiga. Näiteks Marimekko algusaeg oli vaevaline: tootekujundus oli kõrgel tasemel, kuid majandustehingud polnud rentaablid, sest ettevõtte tegevus oli halvasti korraldatud ja omamaist toodangut hindav tarbijaskond väike. Marimekko edu saabus 1950. aastate lõpul, kui ettevõtet hakati pidama tekstiili- ja rõivakujunduse lipulaevaks ning selle toodetest said tarbijate lemmikud. 1970. aastatel teenis Marimekko küll suuri kasumeid, kuid ettevõtte tootekujunduse seisukohalt oli kvaliteet langenud, sest see ei olnud sama uuenduslik nagu varem (Ainamo 1996: 130-149).

A. Ainamo uurimus näitab, et tootekujunduse edukust ei saa hinnata üksnes toote põhjal, vaid tuleb tähelepanu pöörata ka sellele kontekstile, kus toodet valmistatakse ja ostetakse. Tasaraitagi saamine menukaubaks on selgitatav eelkõige just sellega. Hinnates tootekujundust eliidi seisukohalt, olid Tasaraita kaubamärgi tooted (nagu ka teised uued trikoomudelid) Marimekkos iseenesest taseme alandajad, sest need olid kavandatud väga laiale tarbijas- 
konnale ja nendesse riietumine ei osutunud enam loodetud staatusemärgiks. Trikoorõivaid müüdi rohkesti ja just seepärast, et nn tavaline inimene ei pidanud neid sama elitaarseteks nagu Marimekko varasemaid rõivamudeleid. 1970. aastatel valitsenud mõtteviis nõudis rõivadisaineritelt elitaarsuse hülgamist ja kõigile sobivate rõivaste kavandamist. Tasaraitale oli seega olemas selge sotsiaalne tellimus (Ainamo 1996: 149).

A. Ainamo ei selgita "sotsiaalse tellimuse" mõistet täpsemalt, kuid vaadeldes Marimekkot ühelt poolt eliidi ja teiselt poolt lihtrahva vaatepunktist, on mood tema arvates kirjeldatav ühiskonnas aset leidvaid protsesse käsitlevate teooriate abil. Seega vaadeldakse moe muutumist moe levimisena elitaarsetest ringkondadest rahva hulka. Moeuuringute klassik Georg Simmel arutles oma Muodin filosofias (Moefilosoofia; 1986 [1905]) selle põhjuste üle juba 20. sajandi esimese kümnendi alguses, hiljem on sama teemat käsitlenud Pierre Bourdieu (1985). G. Simmeli teooria tugineb mõtisklusel moest kui eraldumisvahendist ja eristajast. Tema arvates kuulub inimloomusesse tendents ühelt poolt sulanduda rühma, teiselt poolt eralduda teistest oma parimate külgedega. G. Simmeli arvates tekkis mood eraldumisteatena kõrgklassis, kes tahtis rõivastuse abil eristuda madalamatest klassidest. Mood laienes, kui keskklass, kes püüdis tabada kõigis valdkondades kõrgklassi stiili, hakkas jäljendama rõivastuses kõrgklassi moodi. Neilt levis mood omakorda rahva sekka. Niiviisi "valgus" mood ühiskondlikus hierarhias allapoole (Simmel 1986 [1905]).

P. Bourdieu (1985) moekäsitlus põhineb samasugusel kolmikjaotusel nagu G. Sammeli oma: eraldumisvõimeline kõrgklass, kultuurihimuline keskklass ja laiad rahvahulgad, kes peavad sellest lugu seni, kuni see muutub tüütavaks. P. Bourdieu arvates on mood teatavasse klassi kuulumise nähtav väljendus, kuid ta vaatleb ka moodi kui omaette välja. Moe kui välja väljendamatu seaduspära on P. Bourdieu järgi eristamine kõigist tema sõnalistest tähendustest: mood on viimseni mood, viimane vahe. Klassitunnused hävivad, kui need kaotavad eraldamisvõime ja muutuvad üldisteks. Kui miniseelik on jõudnud Béthune'i ${ }^{4}$ kaevuriteni, ollakse nullpunktis (Bourdieu 1985: 173).

Teooria moe ringkäigust on kergesti kõrvutatav A. Ainamo uurimisobjektiga ning selle näiteks on Marimekko moodide ringkäik: algul tähendas Marimekko elitaarseid disainrõivaid, hiljem noorterõivaid ja lõpuks sai sellest Tasaraita kaudu kogu rahva mood. Elitaarsest ringkonnast oli Marimekko-mood selleks ajaks - P. Bourdieu järgi - jõudnud ühiskondliku hierarhia madalaimal astmel oleva kogukonnani ja oli seega nullpunktis, kuid see andis müügituluna suure kasumi.

G. Simmeli ja P. Bourdieu hierarilised mudelid selgitavad moe ringkäiku hästi, kuid neid on kritiseeritud inimese isikliku tahte ja subjektiivse vaatevinkli alahindamise tõttu - teooriad näevad moodi järgivat inimest isikliku 


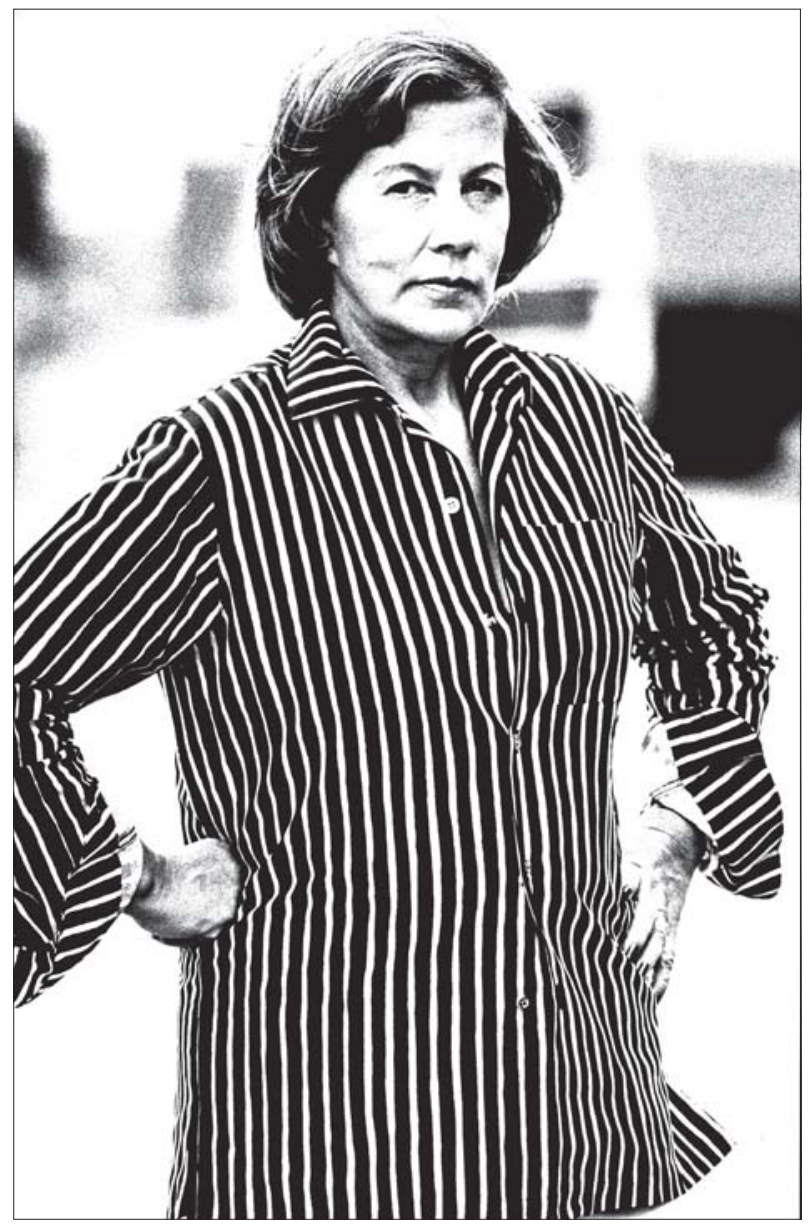

Foto 1. Armi Ratia (1913-1979), Marimekko looja on nii suur legend, et kannab 100 suure soomlase "edetabelis" numbrit 67. Foto: Marimekko pildipank.

tahteta moeorjana. Tegelikult ei ole moe levimine ülalt kindlaks määratud, nagu teooriates mõista antakse. Mõnest turule toodud moeuudisest ei saa moodi üksnes seepärast, et potentsiaalsed ostjad suhtuvad sellesse nii skeptiliselt, et ei osta seda (Davis 1992: 178-179). Uudistootega peab kaasnema illusioon, et see on moekas, kuid peale selle peab see vastama ka kollektiivsele maitsele (Blumer 1968: 343). Vastasel juhul jääb see moekapriisiks, moeajaloo kurioosumiks.

Moe ringkäik on üks viis selgitada A. Ainamo uurimustes nimetatud sotsiaalset tellimust, kuigi see on selgitusmudeliks liiga skemaatiline. Hoopis viljakam on vaadelda seda etnoloogilistes uurimustes kasutatavate meetoditega, kohta ja sotsiaalset keskkonda siduva fenomenina, mis on avaldanud 
mõju sellele, kuidas Tasaraitasse on suhtutud ja suhtutakse. Seega tuleb tähelepanu pöörata ka Herbert Blumeri mainitud kollektiivsetele maitse-eelistustele ja üksiktarbijate valikupõhimõtetele, mille tähtsust rõhutab Fred Davis.

Lähenen Tasaraitale eelkõige kui rõivastumiskultuuri, rõivastumistavade kontekstis olulisele fenomenile. A. Ainamo uurimuses saab sotsiaalne tellimus tähenduse disainesemete kujundamise kontekstis ja see hõlmab ühtlaselt kogu Marimekko tootekujundust. Tekstiili- ja valmisriietekujundust ei saa üksteisest eraldada, kuigi need on disaintoodetena üsna erineva iseloomuga alamvaldkonnad. Ostes Marimekko Tasaraita-särki ei osta üksiktarbija üksnes oma maitse-eelistustele vastavat disaintoodet koju iluasjaks, vaid oma garderoobi sobiva rõivaeseme, mida ta kavatseb kanda. Et määratleda Tasaraita ja muude Merimekko disaini esindavate rõivaste sotsiaalset tellimust ja arutleda nende tähenduse üle, tuleb silmas pidada ka rõivastumise konteksti - neid ideaale ja argipraktikaid, mille alusel inimesed teevad rõivastumisega seotud valikuid.

\section{Marimekko ja Tasaraita ajaloost}

Marimekko loodi 1951. aastal, kuid selle tegevuse algus seostub 1940. aastate lõpul loodud Printexi-nimelise kangatrükiettevõttega. Printexi omanik Viljo Ratia palus tekstiilikunstniku hariduse saanud abikaasal Armil kujundada Printexile mõned lillemustrid, sest need olid tolle aja lemmikud. Armi Ratia keeldus, sest tema arvates ei tohtinud just lillelisi kangaid trükkida. Ta ise ei hinnanud selliseid ja pidas Printexi nišiks teostada tekstiilikunsti valdkonda jäävaid ideid (Ratia 1986: 23). Armi Ratia kujundas ise vaid paar kangamustrit; kujundamise asemel keskendus ta kunstilisele juhtimisele ja otsis kujundajateks ettevõtte ideede elluviimiseks sobivaid kunstnikke. Esimeste seas palkas ta Maija Isola, kelle tekstiilid andsid ettevõtte toodangule uudse, graafilise ilme.

Printexi kangad äratasid huvi, kuid inimesed ei leidnud õiget keskkonda, kus neid kasutada. Seepärast korraldati moedemonstratsioon, kus esitleti Printexi kangastest valmistatud rõivaid eesmärgiga pakkuda näidismudeleid hobiõmblejatele. Moedemonstratsiooni jaoks loodi Marimekko Oy, mis hakkaski tegutsema samal ajal, sest moedemonstratsioonil rõivastest vaimustunud rahvas tahtis kohe teada, kus need rõivad müügil on (Ratia 1986: 2-24; Ainamo 1996: 161).

Armi Ratia visioon Marimekkost oli tõelise esteetilisuse, hea maitse ja uudse rõivastumisfilosoofia küsimus. Tema meelest rõivastusid inimesed paremini, kui neile oli pakkuda selleks eeskujusid ja kvaliteetseid tooteid. Marimekko 
tundis vastutust kui tekstiilidisaini esindaja; ettevõttes ei kujundatud rõivaid selle põhjal, mida inimeset oletatavasti tahaksid osta, vaid valmistati neid oma, Marimekko kriteeriume järgivate mudelite alusel (Ainamo 1996: 160; Ratia 1986: 28). See tähendas Pariisi kui moepealinna eeskujust loobumist. Marimekko rõivamudelid olid täiesti sõltumatud Pariisi moest, kusjuures välditi ka sõna 'mood' kasutamist. Selle asemel räägiti rõivaste valmistamise teenusest või Soome naise riietamisest (Ratia 1986: 28). Rõivakujunduses pöörati erilist tähelepanu kandmismugavusele. Marimekko algusaegade pearõivakonstruktori Vuokko Normesniemi põhimõtteks oli, et rõivas ei tohi olla pingul. Sellel ei tohtinud olla liigseid õmblusi ning volte ja krookeid pidi olema võimalikult vähe. Rõivaste puhul oli peamine nende lõige ja istuvus (Suhonen \& Pallasmaa 1986: 121).

Marimekko disaini põhimõtted esindavad oma aega ehk 1950. aastate ajatut ja lihtsat tootekujundusfilosoofiat. Maailmas tuntakse seda mõistena 'soome disain' (finnish design), mida esindavad muu hulgas Kaj Francki Arabiale kujundatud Kilta serviis, Arteki mööbel ja Tapiola aedlinn. Kõigi nende eesmärgiks oli valmistada harilikke ja argipäevaseid tarbeesemeid esteetilisemana. 1950. aastate esemeesteetika aluseks oli funktsionaalsus, kuid samad esemed pidid täitma üksiti ka kunstitoote rolli (vt Kuusamo 1992: 166). Funktsionaalsus tähendas ka mitmeotstarbelisust. Kilta serviisi puhul tähendas see seda, et samu nõusid sai kasutada nii toidu valmistamiseks, serveerimiseks kui ka säilitamiseks. Sama perioodi Marimekko rõivaste puhul avaldus see selles, et neid ei kujundatud eraldi argi-, visiit- ja piduriietuseks, vaid arvati, et rõivaste kasutusotstarbe määravad nende kandjate vajadused ja maitse. Rõivastumisfilosoofia praktilisus ja rahvahariduslikud eesmärgid avaldusid selleski, et Marimekko rõivad pidid olema kõikjal saadaval. Need ei olnud üksikud salongieksemplarid, vaid kujunda-

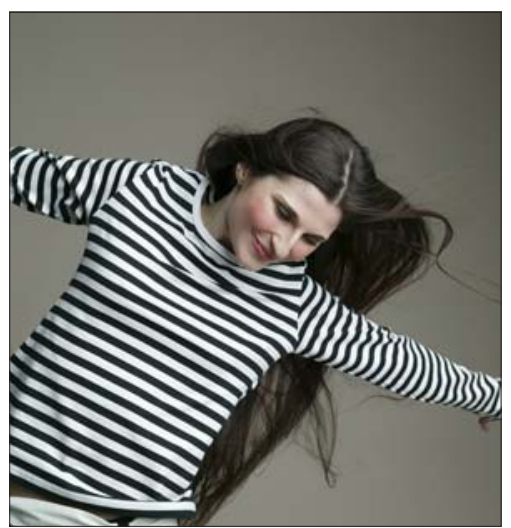

Foto 2. Tasaraita mustvalgetriibuklassika. Foto: Marimekko pildipank. tud valmistamiseks seeriatoodanguna.

Armi Ratia arvates pidi Marimekko eralduma nn soome disainist ja looma täiesti oma stiili, kuid tegelikult sai Marimekko tuntuks just soome moe esindajana. Marimekko rõivaid ei tutvustatud moemessidel, vaid tarbekunstinäitustel.Vuokko Nurmesniemi rõivad said auhinna 1957. aasta Milano triennaalil ja järgmisel aastal osales Marimekko Brüsseli maailmanäitusel. Seal loodi sidemed ameeriklase Benjamin Thomsoniga, kes tutvustas oma skandinaaviapärasele, funktsionaalsele disainile spetsialiseerunud äri 
Design Research kaudu Marimekkot laialdaselt 1960. aastate alguses ${ }^{\mathbf{5}}$ (Ainamo 1996: 135-138). Marimekko andis seega oma panus loomaks Soomest pilti kui kõrgetasemelise disainiga maast. Tõenäoliselt lisas just välismaine tähelepanu Marimekkole kuulsust ja prestiiži ka Soomes.

Tootekujundus- ja rõivastumisideoloogia seisukohalt esindas Marimekko head 1950. aastate disainiideoloogiat, kuid võrreldes tolle aja rõivastumistavade ja -ideaalidega oli Marimekko ennekõike eriilmeline. Tolle ajastu rõivamoe musternäidis oli Christian Dior'i kujundatud New Look: ülimalt naiselik, moodi jäljendav kleit, millel oli liibuv ülaosa, pingul talje ja pikk, lehviv seelikuosa. Pehme ja moodne naiseideaal eeldas taas korseti kandmist. Marimekko särgilaadsed kleidid seevastu olid avarad ja lihtsa lõikega, kuid värvirõómsad ja väliselt kirevad ning jõulised. Ühed arvustasid neid liigse räiguse, teised liigse tavalisuse ja ebanaiselikkuse pärast. Mingeid kogu rahva rõivaid Marimekko toodetest ei saanud, sest ettevõtte tarbijaskonna moodustasid valdavalt haritud ja jõukad linnaelanikud (Turunen 2002: 49).

Laiema soosingu saavutasid Marimekko rõivad 1960. aastatel, mil Marimekkost sai ajaga kaasas käivate inimeste rõivamärk. 1960. aastatel viidi Marimekkos ellu tootekujunduse kõigi valdkondade ideid: lisaks sisustustekstiilidele ja rõivastele müüdi Marimekko kaubamärgi all muu hulgas küünlaid, klaasesemeid, ehteid, keraamikat ja muid dekoratiivesemeid. Firma esteetikat käsitleti laialdase marimekkoliku eluviisina, kuhu kuulusid ka arhitektuur, ruumikujundus, kirjandus, kunst ja ühiskonnaelus osalemine (Wiikeri 1986: 35; Suhonen \& Pallasmaa 1986: 11). Rõivakujunduskontseptsioon oli ka ideoloogiline kontseptsioon; Marimekko kleidis jäeti hüvasti nii kitsaste rõivaste kui ka piiratud mõtetega (heitettiin hyvästit niin ahtaille vaatteille kuin ahtaille aatteille) (Sarje 1986: 50). Rõivad kujundati noorema põlvkonna akadeemiliste ja loovelukutsete esindajatele. Peamiseks sihtrühmaks olid haritud ja moodsad - iseseisvad, teadlikud ja ajaga kaasas käivad - naised, kes said nimeks marinaiset 'marinaised' (Wiikeri 1986: 34). Ühendriikides nimetati Marimekko tooteid intelligentsi vormirõivasteks ja Soomes riietusid sellesse teiste hulgas tuntud noored vasakpoolsed poliitikud. 1960. aastatest alates räägitakse Marimekkost kui kultuurifenomenist - eriti pärast seda, kui ettevõttes hakati kavandama ka Marimajade ja Marikülade ehitamist (Donner 1989: 9).

Annika Rimala ${ }^{6}$ alustas Marimekko rõivakunstniku ametis 1950. ja 1960. aastate vahetusel, kui Marimekko oli Vuokko Nurmesniemi kujundatud rõivaste abil kindlustanud oma positsiooni kindlat laadi rõivastumisfilosoofia esindajana. Tasaraita tootemärgi loomiseni jõudis A. Rimala 1968. aastal. Varasemate kujunduskontseptsioonidega võrreldes oli Tasaraita täiesti uuelaadne Marimekko toode, sest varem ettevõttes trikoorõivaid ei valmistatud. Armi Ratio arvates ei sobinud trikoorõivad kokku kvaliteetseid puuvillrõivaid 


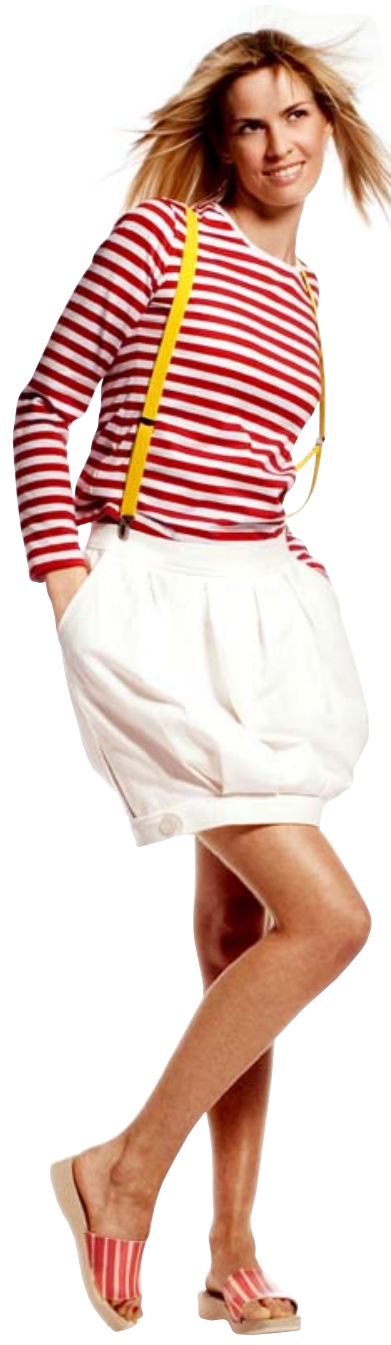

Foto 3. Tasaraita multifunktsionaalne trikoopluus. Foto: Marimekko pildipank.

valmistava Marimekko kaubamärgiga (Maunula 2000: 12). A. Rimala oli nõus, et Tasaraita ei esinda sellist rõivastumistava, millega Marimekkos oli varem harutud (Ainamo 1996: 176), kuid ta tahtis kujundada tolle aja riietumislaadiga sobivaid rõivaid. Tema eesmärk oli kujundada multifunktsionaalne trikoopluus, mida võivad kanda kõik imikutest vanuriteni, nii naised kui ka mehed - kujunduskontseptsioonis sisaldus selgesti maoistlik võrdsustamisideoloogia. Tasaraita võeti mudelite hulka Armi Ratia kõhklustele vaatamata. Ilmselt ei seostanud Marimekko tarbijad Tasaraitat Marimekkoga, sest selle läbimüükjäi tagasihoidlikuks. Järgmisel aastal lasti Tasaraita uuesti müügile, kuid loobuti selle poliitilisuse rõhutamisest. Seekord saatis tooteid turul suurem müügiedu (Ainamo 1996: 176, 179; Ainamo 2003: 34).

Tasaraita eristus kujunduskontseptsioonilt Marimekko varasematest rõivamudelitest, kuid rõivastumiskontseptsiooni seisukohalt esindas seegi “marimekkolikku" tervikliku keskkonna kujundamist. Tasaraita kujunduskontseptsioon tähendab rõivanäidiseid, mille puhul sama lõike järgi valmistatakse erinevat tüüpi rõivaid alus- ja ööpesust trikoopluusideni, mida võib kanda igas kohas ja igasuguste rõivastega. Lihtsa trikoorõivana sobis see oivaliselt masstootmiseks. Hiljem leiti, et Tasaraita mudel on kasutatav ka kodutekstiilidena ja mujalgi. A. Ainamo (1996: 144) arvates kujunes Tasaraitast rahvusvaheline trend, mille võtsid omaks kogu maailma loojad, haritlased ja arvamusliidrid. Soomes viidi Tasaraita abil eelkõige ellu Armi Ratia kõigile sobivate rõivaste idee. ${ }^{7}$ Tasaraita abil laienes Marimekko tarbijaskond ja Marimekkost sai kogu rahva rõivastaja.

\section{Korsetist teksadeni - rõivastumise muutuvad ideaalid}

Tasaraita kujundaja Annika Rimala eesmärk oli luua trikoopluus, mida võis kanda teksadega. See tänapäeval nii lihtsana tunduv põhimõte oli 1960. ja 1970. aastate vahetusel vastus aja väljakutsele ja rõivastumisideoloogia muutumise ilming. 1950. aastatel olid Tasaraita-sarnased rõivastumisfilosoofiad 
olnud üksnes võõrnähud, sest tollases riietuses rõhutati väljapeetud stiili ja rõivastumisetiketi tundmise tähtsust. Ajale iseloomulikke rõivastumisjuhiseid esindavad näiteks Emännän tietokirjas avaldatud rõivastumisnõuanded. Peatükis "Naise garderoob" (Naisen puvustu) (Suova 1958: 902-903) räägitakse, et iga naise põhigarderoobi kuuluvad vähemalt igapäevarõivad, vabaajarõivad, visiitrõivad ja peorõivad. Lisaks antakse juhiseid, millises olukorras mida kanda. Igapäevarõivad on koduriided, milles võib naabri poole kohvi jooma minna või võtta päeval kodus külalisi vastu, kuid kodust kaugemale minnes tuleb need vahetada vabaajarõivaste vastu. Visiitrõivad on erilisteks külaskäikudeks ning pidu- ja õhtukleidid pidulikumateks puhkudeks.

Rõivastuse nüansierinevused tähendasid küsimust situatsioonilistest tähelepanekutest. Tähelepanu vääriv on see, et igapäevased rõivadki pidid olema esinduslikud, sest nendesse riietunult pidi vastu võtma külalisi. Puhtuse hoidmiseks või majapidamistööde tegemiseks oli eraldi põll või töökittel. Riietumisnõuannetes juhiti tähelepanu, et väike garderoob on piisav, kui selle osi kantakse õigesti ja esemeid omavahel sobitatakse. Viimistletud ja olukorrale vastava rõivastuse juures ongi peamine küsimus õigete, koha ja olukorraga sobivate rõivastusesemete valimises. Eelmainitud riietumisjuhiste järgi on vaja vahetada rõivaid mitu korda päevas.

Soome naiste rõivastumistavasid 1920ndatest kuni 1960. aastateni uurinud Päivi Aikasalo (2000) arvates olid rõivastumispiirid kõnealusel ajal kitsad. Nõudlikkus rõivastuse suhtes kasvas eriti 1950. aastatel, mil hoolikaks rõivastumiseks oli vaja nii silma, teadmisi ja kätt kui ka materjalide, lõigete ja värvide tundmist ja sobitamise oskust. Lisaks sellele sõltus rõivastumine 1950.ja 1960. aastatel enesestmõistetavalt sotsiaalsest staatusest - ehk naiste puhul nende meeste staatusest -ja majanduslikust olukorrast. Staatusest üksi ei piisanud, see pidi tulema ilmsiks ka rõivastuses (Aikasalo 2000: 81, 135-136).

Ideaaliks seatud hoolitsetud välimus ja rõivastumisreeglite tundmise rõhutamine peegeldusid 1950. aastate kombestikus, mis oli loomult formaalne ning toonitas traditsioonilisi väärtusi ja sugupoolte rolle. Sellel taustal oli Vuokko Nurmesniemi 1950. aastatel Marimekkole disainitud kujunduskontseptsioon radikaalne. Rangete reeglite nõudmise asemel anti tarbijale vabadus valida rõivaid otstarbekalt ning traditsioonilist moe- ja värvimaailma eirates otsida mõjutusi kunstimaailmast. Antti Ainamo (1996: 134) tõlgenduse järgi tähendas V. Nurmesniemi disain vabanemist konventsionaalsete väärtuste kolmnurgast "kodu, usk ja isamaa" (Ainamo 1996: 134). Vaevalt et rõivaste kandjad esindasid mässumeelset rõivastumist, kuid Marimekko sai harjumuspäraste rõivastumistavade rikkumise tõttu pahakspaneva kriitika osaliseks. Marimekkosid materdati ebanaiselikeks kottkleitideks ja laudajakkideks, mida maitsekal daamil ei sobi kanda. 
"Traditsioonitruude" 1950. aastate järgseid 1960. aastaid on kujutatud radikaalse vaimsuse vabanemise ajana, mis tembeldati noorte- ja popkultuuri aastakümneks. Rõivastumises tähendas see nooruslikkust. Esiteks noortemoodi, mis tegelikult on 1950. aastate "leiutis", kuid iseseisvus 1960ndateks. Teiseks said nooruslikkus ja noortemoest tulenevad mõjutused esimesed juhised üldisest rõivamoest. Selline mõjutaja oli näiteks miniseelik. Edasi võib vaielda selle üle, kes leiutas miniseeliku, Mary Quant või Pierre Courrèges, ehkki Mary Quanti mõjutused rõivastumistavade muutumisele on vaieldamatud. Mary Quant ise on selgitanud, et ta ei leiutanud miniseelikut, vaid üksnes viimistles lõplikult selle rõivastumismoe, mille noored neiud ja naised olid juba omaks võtnud. M. Quanti moekujunduse eeskujuks oli noorte neidude ja naiste hooletu rõivastumine. Tolleaegne moesalongide toodang oli suunatud maksujõulistele täiskasvanud naistele, aga nüüd hakkasid noored juhenduma rõivastumisel üha enam moeloojate tööst (Ewing 1997: 180-181).

Noortemoe kõrval mõjutas rõivastumistavade avardumist ja formaalsuste vähenemist sotsiaalse õhustiku muutus. Sotsiaalseid muutusi peale sundivad liikumised, nagu hipid ja vasakradikaalid, tegutsesid ka rõivastumisvallas või eelkõige seal. Neile oli rõivastumine väljendusvahend, mis aitas ühiskonnakriitilisust harjutades hüljata rõivastumistavad ja moeideaalid. Hipirõivastuses väljendus mitteformaalne individualism ja tahtmine eirata läänelikku kultuskultuuri, vasakpoolsed aga kritiseerisid moe elitaarsust (Evans \& Thornton 1989: 2). Üheks uudse rõivastumise näiteks miniseelikute kõrval olid teksad. Algselt töörõivana kasutatud teksapükstest said 1950. aastatel mässumeelse rõivastumise väljendajad, 1970. aastate saabudes olid need laienenud noore põlvkonna vormirõivaks. Nende töölistaust vastas ajastu vaimule, peale selle nähti teksasid sümboliseerimas mitteformaalsust, võrdsust, vabadust ja mässumeelsust (vt Davis 1992: 70-71).

Teksad olid tähelepanuväärne riietusese noorte ja vasakpoolsete esiletõusu kõrval ka naisliikumisele, mille eesmärk oli murda traditsioonilised sugupoolte rollid ka rõivastumises. Feministliku nägemuse järgi loovad ja uuendavad moemehhanismid väära naiselikkust, milles võimenduvad väljanägemine ja nartsissism. Feministidele oli moe hukkamõistmise puhul oluline moe loodud väära naiselikkuse hülgamine ja vabadus tuua esile ehtne, autentne mina. Praktikas sai feministliku rõivastuse tunnuseks antimood. Välimuses ja rõivastuses pidi olema võimalikult vähe viiteid traditsioonilisele naiselikkusele ja hoolikale moe järgimisele. Rõivastudes tuli olla hooletu ja välimuselt loomulik, meigi ja soengu abil kohendamata. Naised võtsid rõivastumisel snitti meesterõivastest, hakates kandma pükse, näiteks teksasid (Evans \& Thorton 1989: 1-7). 1950. aastate naiselik naiseideaal oli 1970. aastateks asendunud sugude võrdsuse ideaaliga nii nagu korsett teksadega. Võrdõiguslik- 
kusmõtte haripunktiks võib pidada 1970. aastate alguses kasutusele võetud unisex-moodi, mis tähendas täpselt ühesuguseid rõivaid meestele ja naistele. Tüüpilist unisex-moodi esindas teksadest ja T-särgist koosnev rõivastus.

Selles olukorras tuli Tasaraita kui tellimise peale. Selles ühinevad hooletu noortemood ja kriitilised antimoeihalused, peale selle väljendas see sotsiaalset ja sugupoolte võrdsust. See vastas ka selgesti uutele rõivastumiseideaalidele nii ideoloogiliselt kui ka praktilises riietumises. Tasaraita edu on kergesti seletatav noortekultuuri ja uute ühiskondlike liikumiste esiletuleku ja tugevnemisega, aga on põhjust pöörata tähelepanu ka laiemale sotsiaalsele kontekstile, mille põhjal inimesed teevad igapäevaseid rõivastumisvalikuid. 1970. aastatel elasid soomlased mõneti teistviisi kui 1950. aastatel, sest ühiskonna struktuur, tuluallikad ja tarbimisharjumused olid muutunud. Haridus- ja elatustase olid tõusnud ja elulaad muutunud inimeste maalt linna siirdudes (Järvelä 1993: 80-81). Mõned kaubad, nagu külmik, teler ja auto, mis 1950. aastatel olid üksikutel ja mille omamine näitas saavutatud staatust, olid 1970. aastate algul igas kodus tavalised (Pantzar 2000).

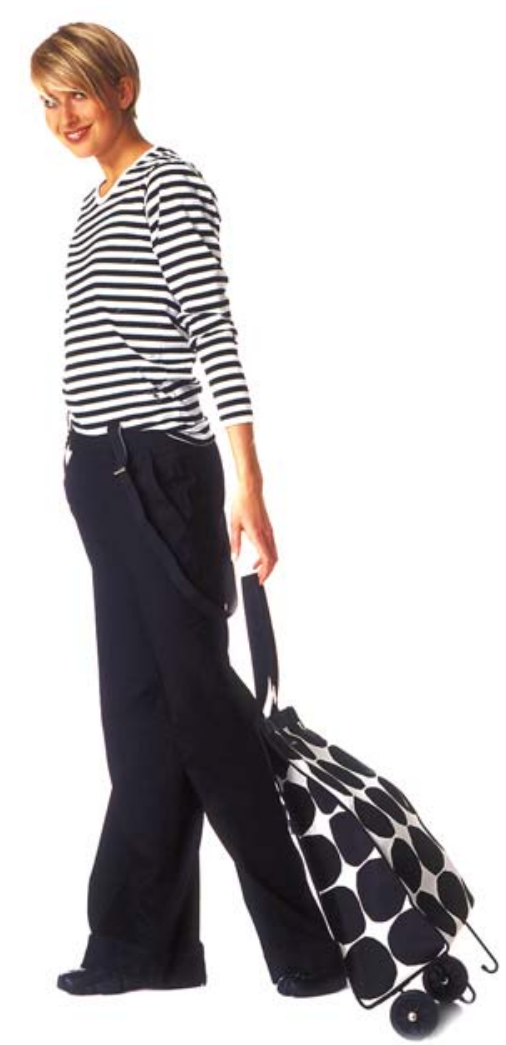

Foto 4. Tasaraita universaalsus on teinud sellest soomlaste klassikalise igapäevarõiva. Foto: Marimekko pildipank.

Rõivastumises tähendas elatustaseme ja elulaadi muutus tegelikult siirdumist valmistajast tarbijaks. 1950. aastatel osteti vaid osa rõivastusest valmisriietena, enamik asju õmmeldi ise või lasti teha õmblejal või moesalongis. 1960. aastatest hakati üha sagedamini ostma kauplustest valmisrõivaid (Aikasalo 2000: 199). Ühelt poolt soosis seda rõivatööstuse jõuline kasv ja rõivapakkujate lisandumine, teisalt olid valmisrõivad ja tarbimine linliku elulaadi loomulik osa.

Marimekkole tähendasid muutused seda, et üha sagedamini oli võimalusi ja tahtmist osta just Marimekko rõivaid, teiselt poolt vastas Tasaraita uuenenud rõivastumispraktikale ja -ideaalidele. Märkimisväärne on ka see, et 1970. aastate keskel korraldas Marimekko uusmüüke nii, et need oleksid hooaegade ja mudelite tasandil jätkuvad. Varem loodi igaks hooajaks täiesti uusi mudeleid. Nüüd olid teatud põhitooted, nt Tasaraita kaubamärgi all valmistatavad rõivad, müügil kogu aeg, üksnes nende värvid muutusid hooajati teataval mää- 
ral (Ratia 2002: 69). Niiviisi said Marimekko põhitooted tuntuks, mis omakorda tegi võimalikukuks rõivaklassika sünni.

Marimekko edu 1970. aastatel, mida soodustas Tasaraita kaubamärgi all valmistatava toodangu menu, võib tõlgendada ka Marimekko rõivastamisideoloogia sobimisega valitseva rõivastumisideoloogiaga. Ühiskond muutus üha võrdõiguslikumaks, radikaalseks peetud mõtted näiteks sugude võrdsusest ja sotsiaalsetest uuendustest olid omaks võetud ning Marimekko rõivastamisideoloogia polnud enam eriline ega erandlik (Ainamo 1996: 142, 148). Ideoloogia, mis oli olnud Marimekko asutamise taga ja tema rõivakujunduse lähtekohaks alates 1950. aastatest, ei esindanud enam eelarvamusteta ja uuenduslikku mõtlemist, vaid soomlaste, õieti noorema põlvkonna argipäevast praktilist rõivastust. Marimekko ei olnud enam teenäitaja, vaid igapäevane rõivastaja. Selle konkreetne näide oli Tasaraita.

\section{Tasaraita isikliku rõivastumise kontekstis}

Intervjueerisin oma magistriväitekirja (Turunen 2002) tarbeks 50-75-aastasi Marimekko rõivastesse vähem või rohkem kirglikult suhtuvaid tarbijaid ning mulle avanes Marimekko ja Tasaraita eespool esitatud rõivastumistõlgendustest märgatavalt mitmekülgsem pilt. Informantide arvamused Marimekkost ja selle rõivaste kandmise kogemused filtreeruvad nende isikliku kogemuse lugude ja individuaalsete eelistuste kaudu ning seetõttu tuleb esile nende vaatenurkade erinevus eelesitatud tõlgendustest. Kohati olid need ka omavahel vasturääkivad.

Rääkides suhtumisest Marimekkosse tunnistasid informandid ikka ja jälle, et nad ei oska seda kirjeldada. Üsna ühtviisi põhjendasid nad Marimekko toodete eelistamist esteetilisuse ja praktilisuse tõttu: rõivad on kvaliteetsed, silmale ilusad vaadata ning need on mugavad ja polüfunktsionaalsed. Peale selle on neis midagi, mis tõmbab nende poole. See miski tegi Marimekkost Marimekko, pani rõivastele ja muudele toodetele oma pitseri ja eristas need muudest kaubamärkidest. See raskesti seletatav "miski" viis neid Marimekko kauplusesse, kui oli aeg osta rõivaid, kodutekstiile ja kingitusi või minna lihtsalt ennast poodidesse vaatama ja imetlema. Üks informant kirjeldas ema suhtumist järgmiselt:

Ma olen üsna sõltuv, selle kohta võib öelda sõltuvussuhe; ei oska näiteks kodutekstiile, ma ei taha osta mingeid muid tekstiile kui Marimekko omi. [---] Ma olen neid nii imetlenud, et kui näen mõnd mulle meeldivat kangast, nii ma selle ostan, kuigi ma üldse ei tea, milleks seda kasutan. 
Foto 5. Elegantsilegendi sünd: koos USA presidendi John F. Kennedyga poseerib ajakirja Sports Illustrated 1960. aasta detsembrinumbri kaanel punases Marimekko kleidis Valge Maja esimene leedi Jacqueline Kennedy.
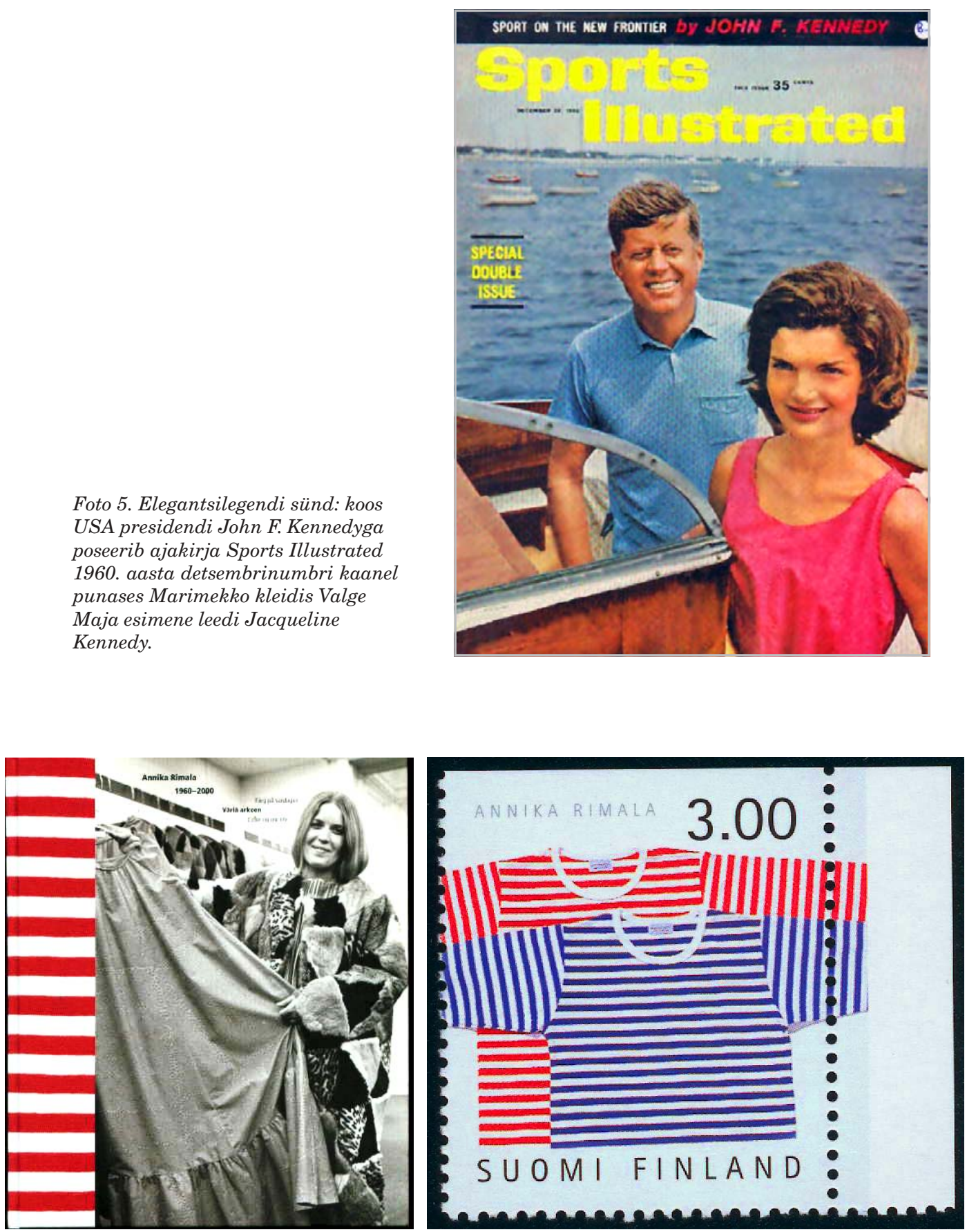

Fotod 6 ja 7. Annika Rimala raamatukaanel ja tema Tasaraita triibusärgid postmargil. 


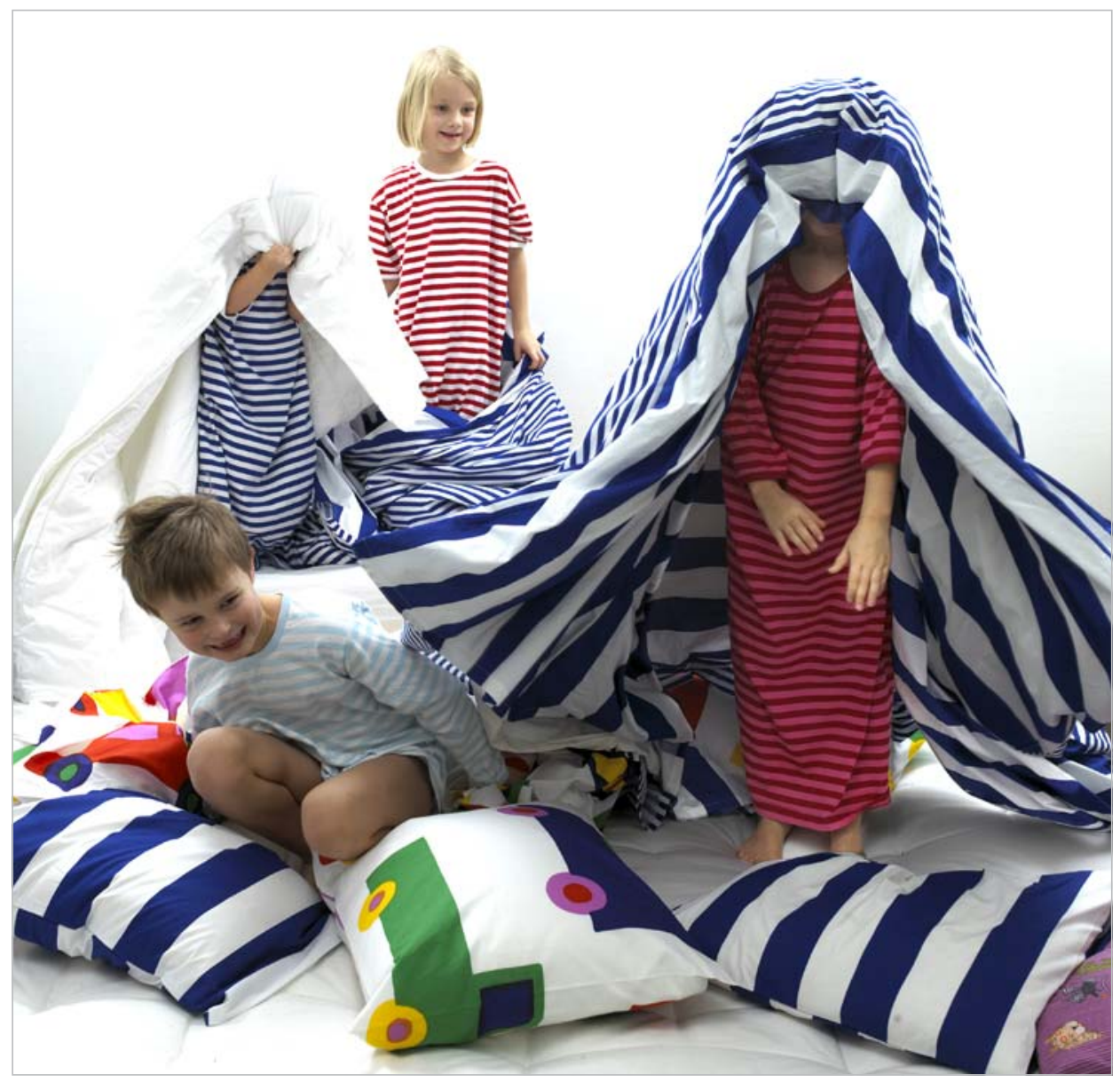

Foto 8. Marimekko ja Tasaraita möllavad Soome lastetoas. Foto: Marimekko pildipank.
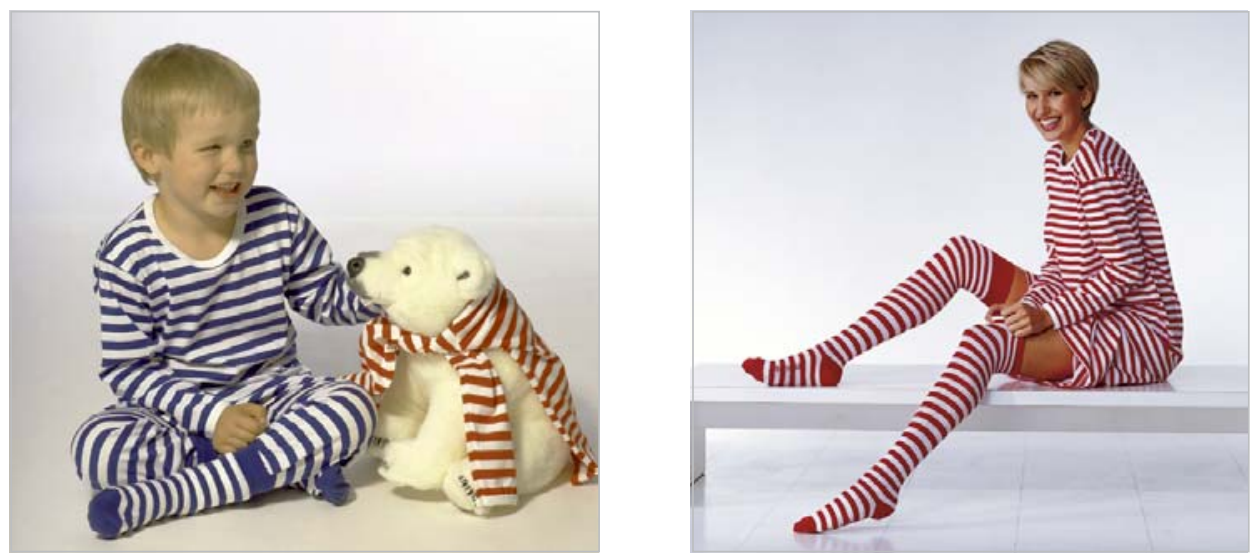

Fotod 9 ja 10. Tasaraita triibumuster sobib igaühele ja igale poole. Foto: Marimekko pildipank. 

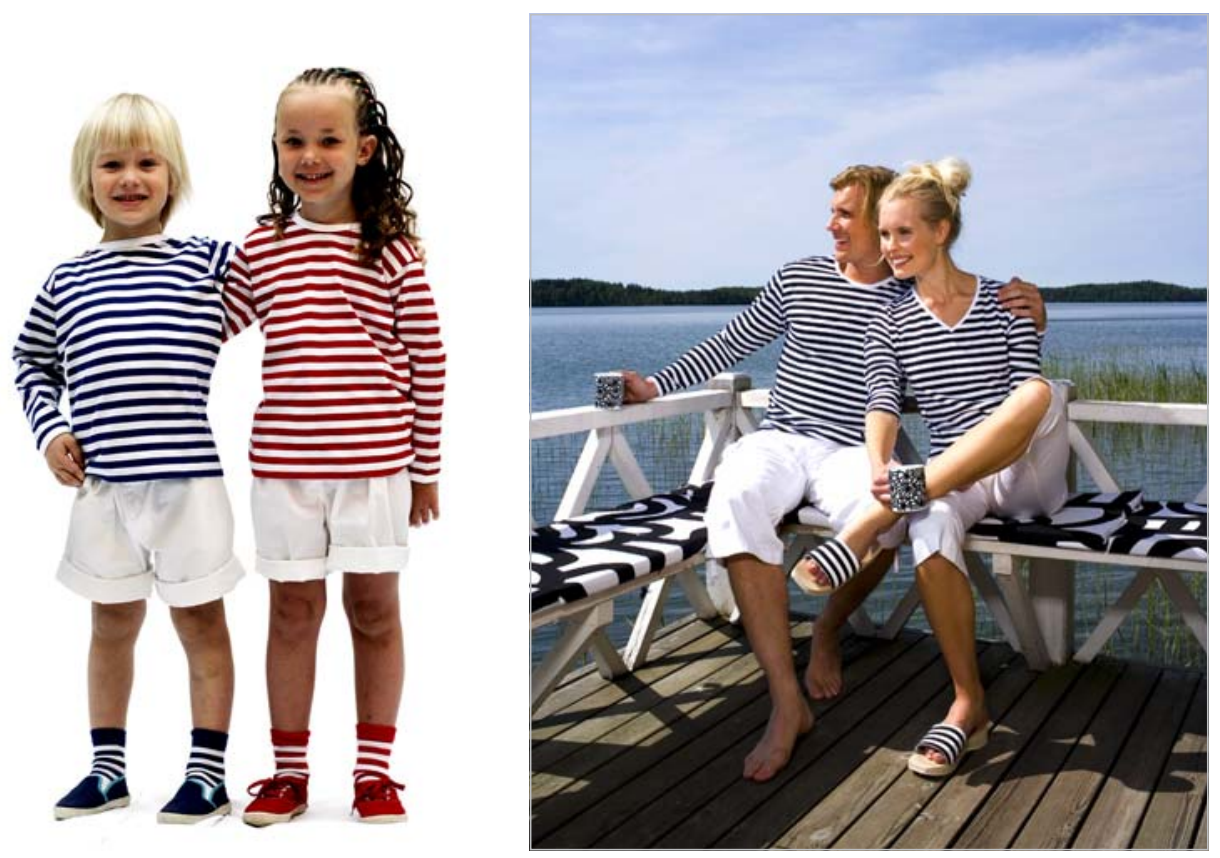

Fotod 11 ja 12. Tasaraita on ühtaegu pidulik ja argipäevane, klassikaline ja romantiline. Fotod: Marimekko pildipank.

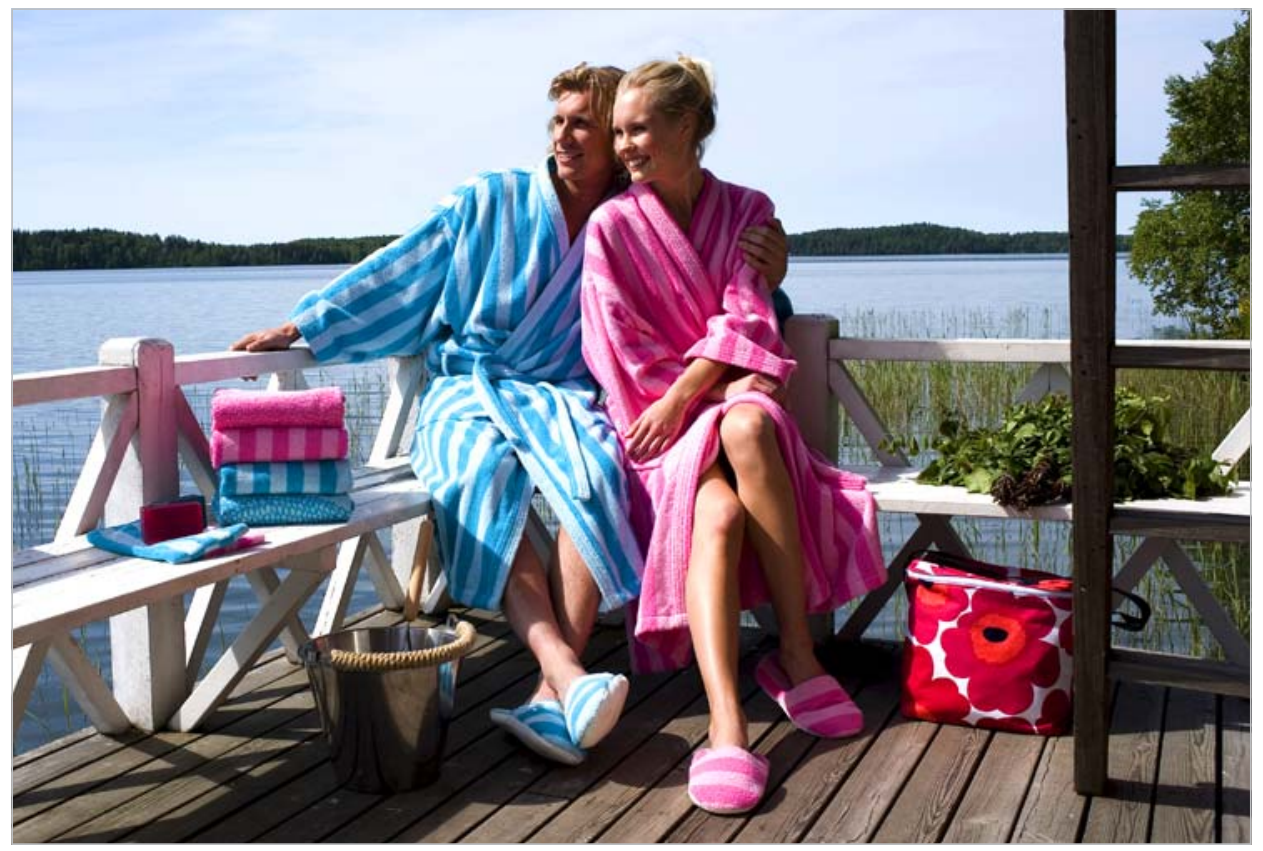

Foto 13. Triibud ei iseloomusta üksnest Tasaraitat, vaid kogu Marimekko klassikat. Foto: Marimekko pildipank. 


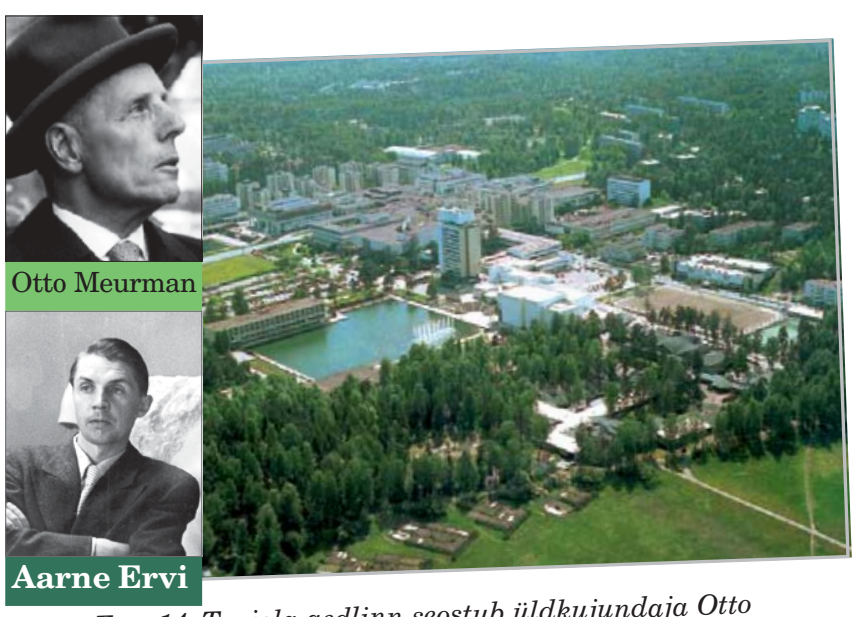

Foto 14. Tapiola aedlinn seostub üldkujundaja Otto Iivari Meurmani (1890-1994), esiarhitekt Aarne Ervi (1910-1977), aga ka Aulis Blomstedti, Alvar Aalto Viljo Revelli, Kaija ja Heikki Sireni ning Reima ja Raili Pietila ning paljude teiste arhitektide nimedega. Just Tapiola

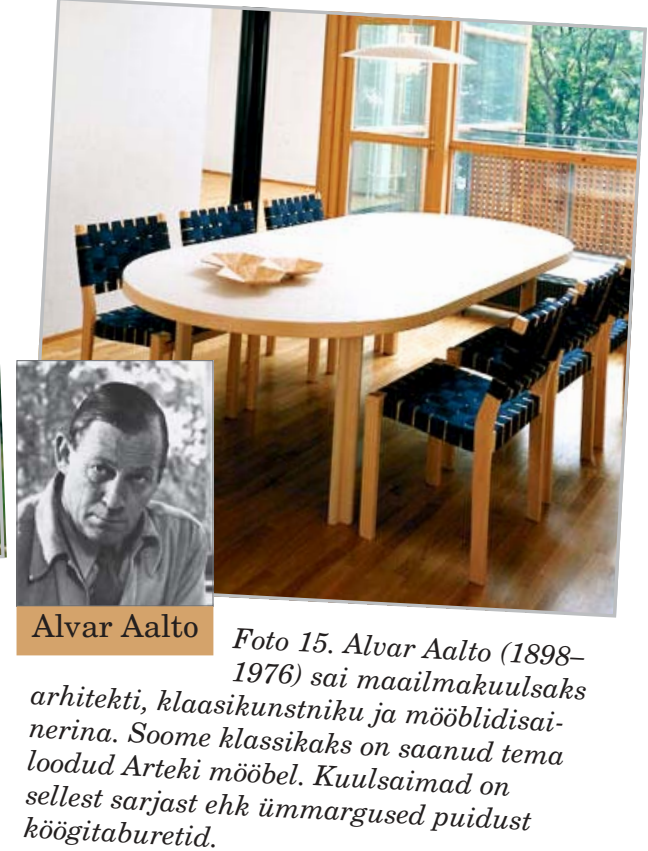

köögitaburetid. ehk ümmargused puidust

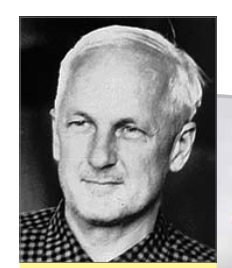

Kaj Franck

1953. aastal Franck (1911-1989) kujundas Teema-sarja eelkäïja.

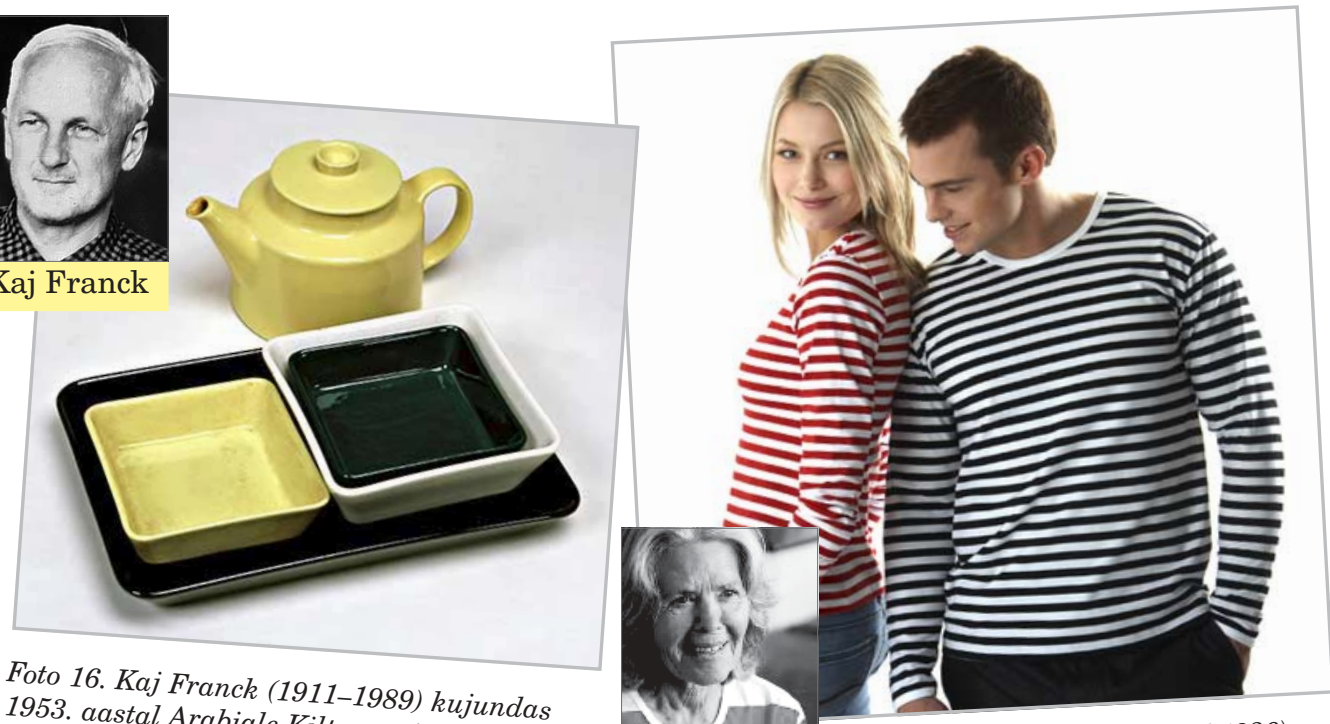

Foto 17. Annika Rimala (sünd 1936) jõudis 1968. aastal Tasaraita triibusär-gi jõudis 1968. ads Marimekko pildipank.

Fotod 14-17. Soome klassika - see kuulus finnish design - on oma põhjamaiselt lakoonilise, puhta ja selge joonega kujunenud üheks soomlaste identideedi oluliseks osaks. 
[---] Tegelikult olen ma nii konksu otsas, et kui on vaja osta endale uusi rõivaid, tuleb esimesena pähe Marimekko. Ma ei oska pidada sellistest rõivastest midagi, mida mü̈̈akse kusagil mujal, mis ripuvad stange peal teistes poodides. Ma ei tea, kas see tuleneb sellest, et ma olengi sellise tegumoe inimene, et need sobivad minu olemusega, sest ma olen niikuinii loomu poolest Marimekko-inimene. Ja mulle tundub, et kõik need, kes kannavad Marimekko rõivaid, on sellised. Et nad on justkui sündinud marimekkolasteks.

Küsitletute vastustest tuli üha selgemini välja, et Marimekko on informantidele terviklik valik. Jutt ei käi üksnes valmisriietest, vaid omast rõivastumisviisist ja selle kaudu iseendast ja enesepeegeldusest. Informandid tunnevad end Marimekko-inimestena, kellele Marimekko on elustiil või üha olulisem osa nendest enestest.

Lähemal vestlusel eluetappidest ja riietumisharjumustest ning -eelistustest Marimekko informantidega ilmnes, et nende suhe Marimekkoga oli saanud sügavalt isiksuse ja isikupärase riietumise osaks. Informandid jagunesid kahte vanuserühma, kellest vanemad olid sündinud 1920. ja 1930. aastatel ning nooremad 1940. ja 1950. aastatel. Nendel kahe rühma erinevused ilmnevad nii riietumistavades kui ka Marimekko rõivaste käsitlemisel. Erinevused tulid selgelt esile suhtumises Tasaraitasse.

Vanemad informandid tutvusid Marimekkoga noorena 1950. aastatel. Marimekko kleidid olid neile esteetilisest ja kujunduslikust seisukohast teretulnud vastukaaluks lillelistele narmaskleitidele ja muudele 1950. aastate moenähtustele. Marimekko kleitidel oli seega tellimust. Informandid mainisid tihti, et Marimekko kleidid on esiteks värvirõõmsad, teiseks meeldib nende lõige. Kleite hinnati endale sobivaks ja hästiistuvaks - nende kandmine võimaldas end vabamalt tunda ja vabamalt liikuda:

1960. aastate kleidid olid hästi liibuvad. Seega on selge, et need sobisid küll sihvakatele ja saledatele, aga kes oli selline, nagu mina... veidi suure kondiga ja pikaseljaline ja laiaõlgne, siis muidugi tundusid Marimekko kleidid kohe täiesti vajalikuna. Nii ma kolisin oma esimesse Marimekko kleiti ja sellest ajast peale olen neis olnudki. Kasutan väljendit "kolisin kleiti”, kuna see oli pääsemine mulle ja mu kehaehitusele ning selle sees on hea olla.

Need Marimekko puuvillkleitide austajad - või neisse lausa kolinud - on valinud need kleidid oma rõivastusstiiliks. Muutused Marimekko kontseptsioonides on tähendanud kaugenemist "ehtsast ja algupärasest" Marimekkost. Osa vanematest informantidest on nende muutustega kohanenud ning hakanud 
kandma trikoorõvaid ja hiljem Marimekko kostüümkleite. Kirglikele kleidikandjatele tähendas Marimekko uuenemine Tasaraita suunas nende riietumisstiili hävimise ohtu. Tasaraita soosis enam trikoomudeleid ja sellevõrra vähem kleite. Informandid küll möönsid Tasaraita edu - valmistati ju sellegi kaubamärgi all hea kvaliteediga, kauakestvaid ja esteetiliselt kauneid tooteid -, aga nad ei tundnud end nendesse riietesse sobivat. Siinkohal näide suhtumisest trikoorõivastesse:

Ma ei ole avalikult sellistes riietes käinud. Küll aga kodus, kus neid võib kanda koduriietena, koristamisriietena ja muu sellisena, öösärgina samuti. Aga ma ei tundnud ennast nendes lohmakates hästi, need oleksid nõudnud seelikukandmist. Ja et ma olen pealegi kleidiinimene, siis ei sobinud.

Selle informandi tähelepanekute järgi hakkasid Marimekko-inimesed Marimekkost vähem rõivaid ostma või lõpetasid selle üldse kas mõneks aastaks või aastakümneteks, sest poodides ei leidunud enam meelepärast kaupa. Vanade lõigete järgi hakati kleite uuesti valmistama 1990. aastatel ja need võeti rõõmuga vastu.

Järgmise põlvkonna suhtumine Tasaraitasse on eelmisele vastandlik. 1960. ja 1970. aastate noortele on just Tasaraita tüüpiline Marimekko rõivas. Marimekko oli neile tuttav ja ihaldusväärne objekt juba enne trikoomudelite tulekut, aga just Tasaraita tegi Marimekkost selle, millena teda tuntakse. Vanemate informantide jutust ilmneb, et Marimekko riided esindasid 1950. aastatel ja 1960. aastate alguses erilist rõivastumisviisi, aga noorema põlvkonna kujutlusis olid Marimekko rõivad trendikad ja neid kandsid "kõik". Nad olid eriti vaimustunud Tasaraita särkidest. Neid võis kanda igal pool ja need sobisid suurepäraselt just teksadega. Oma panuse andis ka ainulaadne stiil ja selge värvivalik.

Tasaraita riided on nende meelest mugavad ja sobilikud igal pool kandmiseks. Informandid jutustavad, kuidas armastajapaaridel olid ühesugused triibulised särgid ja hiljem riietasid nad oma lapsed Marimekko trikoorõivastesse, nn maritrikoodesse. Vanematele informantidele oli paarikeste ühtemoodi riietumine võõras. Vanem põlvkond ei kasutanud Tasaraita tooteid muuks kui öösärkideks, aga nooremale põlvkonnale olid need põhirõivad, mida sobib kanda nii pidu- kui ka argipäeval. Nende kogemuste järgi kandsid 1970. aastatel Tasaraita riideid ainult noored ja sama põlvkond kannab neid siiamaani. Informandid oletavad, et praegused noored ei näe ega taju Marimekkot ja Tasaraitat samamoodi nagu nemad ega võta seega omaks ka Marimekko rõivastumisviisi. Näiteks oli ühe informandi arvates Marimekko rõivastus loomulik jätk teismeliste hipimoele. Mõne informandi lapsed on vaimustuses Mari- 
mekkost, aga informandid kahtlustavad, et noored kannavad Tasaraita rõivaid sellepärast, sest vanemad ostavad neid. Samuti loodavad informandid, et noored avastavad Marimekko, aga täiskasvanuks saavate laste emad teavad, et emade eelistused ei mõjuta oluliselt laste rõivstumisvalikuid.

Ühele informandile tähendas Marimekko ja eriti Tasaraita poliitilist riietumist. Ta hakkas kandma Marimekko rõivaid 1970. aasta paiku, olles tulnud maalt Helsingisse õppima:

See oli tol ajal midagi uut, need triibud, ja kindlasti ka see, et sellel oli hea maine ja head lõiked. See sobis ka tolle aja vaimuga. Marimekko toodete üksmeelse kandmisega aeti täpselt seda ühiskondlikku asja, mida Soomes tol ajal aeti. Vaadati Soome piiride taha ja saadi sealt mõjutusi ning kõik see sõjavastasus ja muud asjad kuulusid sellesse aega samamoodi nagu Marimekko.

Tasaraita on tema arvates teatud ajastule iseloomulik rõivastus teatud eluetapil. Tasaraita oli vasakpoolsete vaadetega inimeste teadlik valik ja tunnusmärk. Marimekko aga oli talle teatud ajal teatud eluetappi kuuluv riietumisviis:

[---] siis see kadus, 1980. aastatel, neid osteti üsna vähe. [---] Enam ei olnud vaja neid aateid näidata, mis Marimekkol seal sellal kindlasti olid. Et peab arvesse võtma, nagu Marimekkol oli just Tasaraita, võrdõiguslikkust, see ei tundunud iseenesest enam nii väga radikaalse rõivastusena, pärast seda, kui need lapsed olid selles.

Sealtpeale ei ole ta kandnud ega ostnud Marimekko tooteid, küll aga võttis ema Marimekko-vaimustuse üle tema kahekümneaastane tütar. Tütar otsis Marimekkost 1970. aastate vaimu ja hankis endale täikalt vanu Marimekko rõivaid.

\section{Oma ja ehtne - Tasaraita osa kollektiivsetes ja üksikisiku mälestustes}

Informantide kirjeldustest ilmnes selgesti, et Tasaraita ei ole näiteks mingi "kogu rahva rõivas", millena on seda kujutatud. Ka Tasaraita positsioon poliitilise rõivastusena on vastuoluline. Eriti hämmelduvad vanemad informandid, kui neile sellekohane küsimus esitada: nende meelest ei sobinud vasakradikaalsus ja Marimekko üldse kokku. Nooremate meelest ühendas Tasaraita 1960. ja 1970. aastate vaimu, aga ainult ühele neist assotsieerus Marimekko ja eriti Tasaraita selgelt poliitikaga. Esimesena nimetatud rühm ei püüdnud 


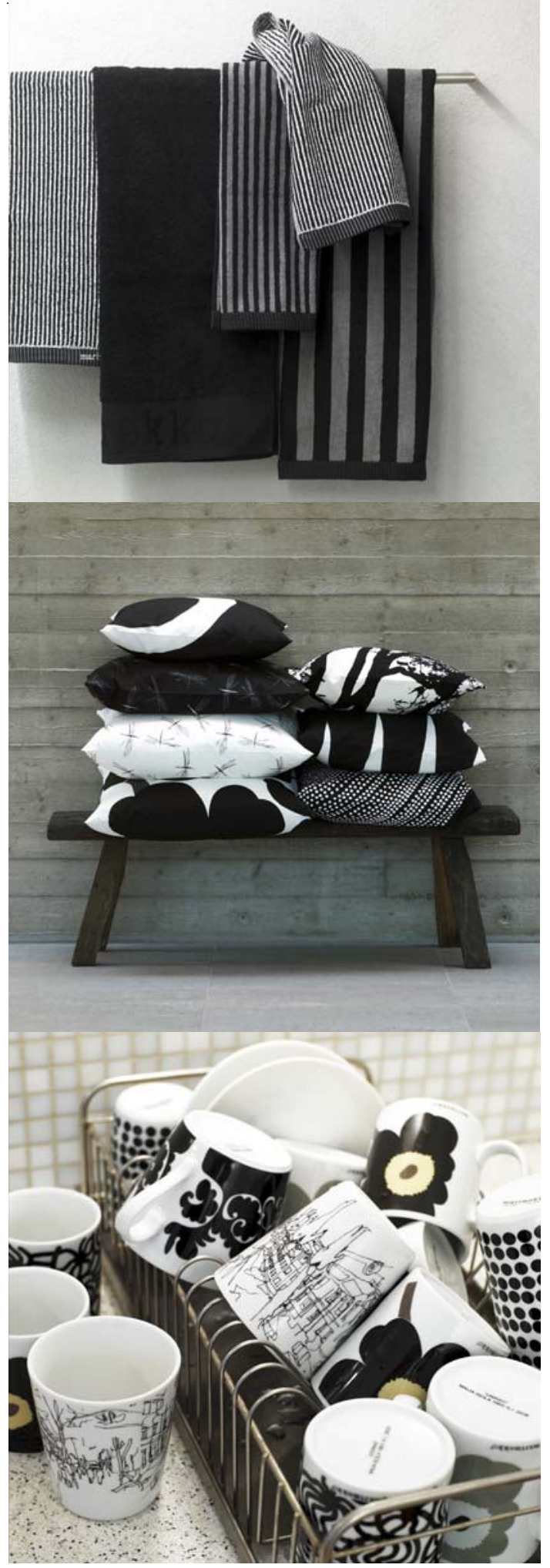

Foto 18-20. Marimekko pole ammu enam üksnes valmisrõivatööstus, isegi mitte tekstiilitööstus, vaid kujundab edukalt kogu elukeskkonda. Fotod: Marimekko pildipank. 
näha Tasaraita kaubamärki võrdõiguslikkust väljendava rõivastusena ja teise rühma arvates oli teisejärguline, kuidas Tasaraita uut turundusstrateegiat kujundati. Viimasena nimetatud informandi arvates Tasaraita suunamuutus olukorda ei mõjutanud.

Tõlgendamise keerukus ja vastuolulisus ei kõiguta siiski mingil määral Tasaraita positsiooni klassikaliste rõivastena; tähenduste keerukus muudab hoopis Tasaraita kultuuriliselt tähenduslikuks. Tasaraita on välja kujundanud palju rõivastumiseelistusi ja -tavasid. Eriti silmatorkav on see arutlustes 1960. ja 1970. aastate rõivastuse ja toona aset leidnud muutuste kohta. Siis mindi moereeglite järgimiselt ja teravalt eristumistelt üle moest mittehoolimise ja võrdõiguslikkuse esiletoomisele. Intervjuudes ilmneb siiski, et muutusi ei tõlgendata kuigi üldistena. Suuremad arengujooned on pealispind, mille all peitub mitmesuguseid viise muutusi tabada ja teoks teha. Mõningate inimeste rõivastumistavades ja -käsitlustes ei olnud muutustel mingit mõju või on seda kogetud vaid omast lähtepunktist ja isiklikest rõivastumistavadest ja -eelistustest lähtudes. Informantide suhtumine Tasaraitasse on niivõrd vastuoluline, et nad tajuvad seda Marimekkosse suhtumise kaudu. Vanemate informantide meelest kaugendas Tasaraita Marimekko "ehtsast" Marimekkost, samas kui nooremate silmis ongi Tasaraita "ehtne" Marimekko. Teisalt võib eri vanuses informantide erinevat suhtumist Tasaraitasse selgitada muutustega nii Marimekkos kui ka rõivastumistavades.

Informantide suhtumised näitavad, et Marimekko ja Tasaraita saavad tähenduse nende isikukohaste tähenduste maailma osana. Tarbimise uurija Grant McCrackeni (1990) arvates püüavad tarbijad alati muuta esemed endale tähenduslikuks. Kui see ei õnnestu, tundub inimesele, et ese ei ole "oma". Seetõttu püütakse esemeid reklaamimise ja turustamise kaudu liita teatud tähendustega. Tarbija seisukohalt on toode anonüümne nii kaua, kuni ta annab sellele lõpliku tähenduse. Mõnikord otsivad tarbijad esemetelt just neid tähendusi, mida tootja ja reklaamija neile liidavad, mõnikord annab esemele tähenduse selle ostja ja see on täiesti sõltumatu reklaami abil loodud tähendusest (McCracken 1990: 84-88).

Informantidele on Marimekko puhul oluline, et see tundub "omana". Igaüks kogeb seda siiski erinevalt. Rõivaid ostes on eriti tähtis, et need kandjale igati sobivad, sest rõivad kuuluvad olemuslikult isiklikku, intiimsesse sfääri (Vesterinen 2001: 25). Rõivastumisuurimustes määratletakse rõivaid tihti "teise kehana", sest tahetakse esile tuua rõivastuse tähendust inimese identiteedile. Rõivastumissuurija Joanne Entwistle rõhutab rõivaste tähendust kogu välispildi ja minapildi loomisel. Rõivas mitte ainult ei kaitse inimest ega peida looduslikku ihu, vaid see on ka teatud viis kogeda ja esile tuua keha. Riietus mitte ainult ei väljenda identiteeti, vaid on osa sellest (Entwistle 2001: 33). 
Kui vaetakse Tasaraita positsiooni soomlastele olulise eseme või rõivana, selgub, et nii mõnelgi on sellega isiklik, kogemuslik suhe, mis on 35 aastaga saanud ühe sugupõlve pikkuse ajaloo. Seega on Tasaraital tähendus ühese, konkreetse kihistusena, nagu esemetel on tähendus isikuloo seisukohalt, selgub etnoloog Orvar Löfgreni (1990) uurimusest. O. Löfgreni järgi on esemed kultuurilised ladestused, mis jutustavad elu varasematest ajajärkudest kohtade, tunnete ja kogemuste meenutamise kaudu. Seega on neil oluline osa mälu tugisamba ehk isikuloolise verstapostina (Löfgren 1990: 198-199.) Kõigile tuntud rõivana on Tasaraita osa soomlaste kollektiivsest mälust. See esindab püsivust ja järjepidevust, sest vana särgi asemele võib osta uue - või nagu nooremad põlvkonnad Tasaraitat võtavad: täiskasvanuna võib riietuda samamoodi nagu lapsena. Mõnigi õnnelik on pärinud vanematelt vana Tasaraita särgi. Nende nägemuses saab ajatu Tasaraita särk tähenduse nostalgilise mälestusesemena, mis mäletab aega enne selle kandja sündi.

Nagu teksad, nii on ka Tasaraita muutunud ühe ajajärgu uudsest või isegi mässavast rõivastusest mitmetel puhkudel kantavaks üldrõivaks. 1960. aastate lõpus alanud ja üha tugevnenud soosing näitab samuti, et Tasaraitaga seostuv rõivastumisviis ei ole kaotanud ajakohasust. Rõivastumine on vaba ikkagi selles mõttes, et igaüks võib ise valida stiili ja etikett ei määra igapäevast rõivastumist sel viisil nagu 1950. aastatel. 1970. aastatel omaks võetud lõtv ja moodi eirav igale poole sobiv rõivastumisstiil on teisalt jälle mõjutanud osaliselt arvamust soomlastest kui maitsetult riietuvatest inimestest, kes ei mõista, et valged tennisesokid ja tuulepluus on spordirõivad. Tasaraita ja tuulepluuside rohkuse taga on samal viisil ebamoodsust õhkuv ja erinevusi vältiv rõivastumisideoloogia. Selles mõttes on need soomlaste "rahvariided". Rahvuslikult tähenduslik on Tasaraita selles mõttes, et seda on osavalt kasutatud soome rahva Soome-pildi ja soomlaste identiteedi määratlemisel. Jacqueline Kennedy-Onassise toel kerkis Soome maailma moekaardile - vähemalt soomlaste endi silmis.

Tõlkinud Maarja Villandi

\section{Kommentaarid}

${ }^{1}$ Originaal: Arja Turunen. Marimekon Tasaraita pukeutumisilmiönä. J@rgonia 3. Jyväskylä: Jyväskylän yliopiston historian ja etnologian laitos 2004 (http:// virtuaaliyliopisto.jyu.fi/jargon/jargonia/marimekko). Kirjutise aluseks on autori 2002. aastal Jyväskylä Ülikooli Ajaloo ja Etnoloogia Instituudis kaitstud magistritöö Marimekkoihmisiä ja marimekkomuotia. Etnologinen tutkimus Marimekosta pukeutumisilmiönä. 
${ }^{2}$ Niisuguseid määratlusi on kasutatud nii Marimekko 35-aastasest ajaloost kõnelevas näitusekataloogis Marimekkoilmiö (Suhonen \& Pallasmaa 1986) kui ka Annika Rimala elutöö ülevaatenäituse Annika Rimala 1960-2000: Väriä arkeen (Maunula \& Tarschys 2000) kataloogis.

${ }^{3}$ Pilt on avaldatud näiteks teoses Arkinen kumous: Suomalaisen 1960-luvun toinen kuva (Peltonen \& Kurkela \& Heinonen 2003: 37).

${ }^{4}$ Béthune, väike söekaevanduslinn Põhja-Prantsusmaal Nordi departemangus (toim).

${ }^{5}$ Marimekko müügi algusest peale on Ühendriikidest kujunenud mingis mõttes Soome eksporttööstuse Tuhkatriinu. Praegugi Marimekkoga kaasnevate legendide kangelanna on Jacqueline Kennedy. Tema ostis esimesest Ühendriikidesse eksporditud partiist mõningad eksemplarid Marimekko rõivaid. Neid kopeeriti laialdaselt kogu Ühendriikides, sest ostureisil olid poliitilised eesmärgid. Ühendriikides käis 1959. aastal presidendivalmiskampaania ja selle vahendite hulka kuulus ka presidendikandidaadi abikaasa rõivastumine. Presidendikandidaadi John F. Kennedy abikaasat Jacqueline’i oli halvustatud elitaarse Prantsuse haute couturé̉i eelistamise eest. Näitamaks, et väited tema elitaarsuselembusest pole õiged, soetas ta vähemelitaarseid skandinaavia disaini esindavaid rõivaid puhkudeks, kus kohal oli ajakirjandus. 1960. aasta detsembris oli ajakirja Sports Illustrated kaanel pilt presidendipaarist, millel Jacqueline Kennedy kannab punast Marimekko kleiti (vt Suhonen \& Pallasmaa 1986: 23).

${ }^{6}$ Rimala on moelooja praegune perekonnanimi, Tasaraita toodete kujundamise ajal oli ta perekonnanimi Piha. Marimekko kunstnikuna alustades kandis ta nime Annika Reunanen. Selguse ja ühtluse pärast kasutatakse käesolevas kirjutises nime Rimala.

${ }^{7}$ Selgitusi Tasaraitaga seotud poliitilisuse rõhutamise kohta. Näiteks mainigem Suomen historia 8. köite (Avikainen \& Hetemäki 1988) artikleid "Paasikiven aika" ja "Kekkosen aika”, milles räägitakse uusvasakpoolsuse kasvust 1960. aastate lõpul. Teksti juures lk 198 on pilt Soome Sajakomitee (Suomen Satankomitea) propagandaürituselt 14. mail 1969. Pildiallkirja kohaselt liikmete radikaalsusele osutavad läbimõeldult lohakas rõivastus, pikad juuksed, habe ja õllepudelid. Vaevalt on see juhus, et pildil oleval sajakomiteelasel Erkki Tuomiojal on seljas Tasaraita trikoopluus.

\section{Kirjandus}

Aikasalo, Päivi 2000. Seuratkaamme järkevää ja terveellistä muotia: Naisten pukeutumisihanteet ja vaatevalinnat 1920-luvulta 1960-luvun lopulle. Kansatieteellinen arkisto 47. Helsinki: Suomen Muinaismuistoyhdistys.

Ainamo, Antti 1996. Industrial Design and Business Performance: A Case Study of Design Management in a Finnish Fashion Firm . Acta Universitatis oeconomicae Helsingiensis $=$ Helsingin kauppakorkeakoulun julkaisuja A: 112. Helsinki: Helsinki School of Economics and Business Administration.

Ainamo, Antti 2003. Marikylä - moderni utopia. Peltonen, Matti \& Kurkela, Vesa \& Heinonen, Visa (toim). Arkinen kumous: Suomalaisen 1960-luvun toinen kuva. Suomalaisen Kirjallisuuden Seuran toimituksia 849. Helsinki: Suomalaisen Kirjallisuuden Seura, lk 19-37. 
Peltonen, Matti \& Kurkela, Vesa \& Heinonen, Visa (toim) 2003. Arkinen kumous: Suomalaisen 1960-luvun toinen kuva. Suomalaisen Kirjallisuuden Seuran toimituksia 849. Helsinki: Suomalaisen Kirjallisuuden Seura.

Bourdieu, Pierre 1985. Sosiologian kysymyksiä. Tampere: Vastapaino.

Blumer, Herbert 1968. Fashion. Sills, Davis L. (toim). International Encyclopedia of the Social Sciences 5. New York: The Macmillan Company, lk 341-345.

Davis, Fred 1992. Fashion, Culture and Identity. Chicago \& London: The University of Chicago Press.

Donner, Jörn 1986. Unelmat ja todellisuus. Suhonen, Pekka \& Pallasmaa, Juhani (toim). Marimekkoilmiö. Espoo: Weilin + Göös, lk 8-18.

Entwistle Joanne 2001. The Dressed Body. Entwistle, Joanne \& Wilson, Elizabeth (toim). Body Dressing. Oxford \& New York: Berg, lk 33-58.

Evans, Caroline \& Thornton, Minna 1989. Women and Fashion - On a New Look. London: Quartet Books.

Ewing, Elizabeth 1997. History of 20th Century Fashion. London: B.T Batsford Ltd.

Järvelä, Marja (1994) Elämäntavan näkökulma. Kupiainen, Jari \& Sevänen, Erkki (toim). Kulttuurintutkimus: Johdanto. Tietolipas 130. Helsinki: Suomalaisen Kirjallisuuden Seura, lk 74-96.

Kuusamo, Altti 1992. Esineiden järjestyksestä: Sisustuksen marginaalit 1950-luvulla. Makkonen, Anna (toim). Avoin ja suljettu: Kirjoituksia 1950-luvusta suomalaisessa kulttuurissa. Suomalaisen Kirjallisuuden Seura. Suomalaisen Kirjallisuuden Seuran toimituksia 567. Helsinki: Suomalaisen Kirjallisuuden Seura, lk 163-177.

Löfgren, Orvar (1990) Tingen och tidsandan. Arvidsson, Alf et al. (toim). Människor \& föremål: Etnologer om materiell kultur bidrag av K.-O. Arnstberg. Kungl. Skytteanska samfundets handlingar 38 A. Stockholm: Carlssons, lk 187-208.

Maunula, Leena 2000. Annika Rimala, 40 vuotta tekstiilisuunnittelua. Maunula, Leena \& Tarschys, Rebecka 2000. Annika Rimala 1960-2000: Väriä arkeen. Helsinki: Taideteollisuusmuseo, lk 10-13.

Maunula, Leena \& Tarschys, Rebecka 2000. Annika Rimala 1960-2000: Väriä arkeen = Färg på vardagen = Colour on Your Life. Helsinki: Taideteollisuusmuseo.

McCracken, Grant 1990. Culture and Consumption: New Approaches to the Symbolic Character of Consumer Goods and Activities. Bloomington: Indiana University Press.

Niskanen, Annamari 2003. Ikea + paavi = antiikki. Helsingin Sanomat NYT-liite 44, lk 8 .

Pantzar, Mika 2000. Tulevaisuuden koti: Arjen tarpeita keksimässä. Helsinki: Otava. Ratia, Ristomatti 2002. Paha poika. Helsinki: Otava.

Ratia, Viljo 1986. Alkuvuosien kiemuroita. Suhonen, Pekka \& Pallasmaa, Juhani (toim). Marimekkoilmiö. Espoo: Weilin \& Göös, lk 23-29.

Saarela, Pekka 2000. Lukijalle. Maunula, Leena \& Tarschys, Rebecka 2000. Annika Rimala 1960-2000: Väriä arkeen. Helsinki: Taideteollisuusmuseo, lk 5. 
Sarje, Kimmo 1986. Rätti on meidät vapauttava! Suhonen, Pekka \& Pallasmaa, Juhani (toim). Marimekkoilmiö. Espoo: Weilin \& Göös, lk 48-56.

Simmel, Georg 1986. Muodin filosofia. Esseekirjasto. Helsinki: Kustannus Oy Odessa.

Suhonen, Pekka \& Pallasmaa, Juhani (toim) 1986. Marimekkoilmiö. Espoo: Weilin \& Göös.

Avikainen, Paula \& Hetemäki, Ilari (toim) 1988. Suomen historia 8: Paasikiven aika \& Kekkosen aika. Espoo: Weilin \& Göös.

Suova, Maija (toim) 1958. Emännän tietokirja. Porvoo: WSOY.

Turunen, Arja 2002. Marimekkoihmisiä ja marimekkomuotia: Etnologinen tutkimus Marimekosta pukeutumisilmiönä. Julkaisematon pro gradu-työ. Jyväskylän yliopisto, Historian ja etnologian laitos (http://selene.lib.jyu.fi:8080/gradu/v02/G0000056.pdf 29. august 2006).

Vesterinen, Ilmari 2001. Esinepeli. Vesterinen, Ilmari \& Lönnqvist, Bo (toim). Pandoran lipas: Virvatulia esineiden maailmasta. Tietolipas 179. Helsinki: Suomalaisen Kirjallisuuden Seura, lk 13-60.

Wiikeri, Anna-Liisa 1986. Marimekko ja muoti. Suhonen, Pekka \& Pallasmaa, Juhani (toim) 1986. Marimekkoilmiö. Espoo: Weilin \& Göös, lk 34-40.

\section{Summary}

\section{Marimekko's Tasaraita Phenomenon}

Arja Turunen

Key words: democracy, Marimekko, fashion philosophy, youth apparel, clothing design, clothing style, Finnish classics, social equality, Tasaraita

The article discusses the history of Marimekko, which has become a classic clothes company in Finland, and the phenomenon of the striped T-shirt marketed under the Tasaraita brand. Initially Marimekko stood for elitist designer clothes, later youth apparel and, with the Tasaraita, eventually became the people's fashion. The principles of Marimekko design are representative of their period, i.e. the timeless and simple product design philosophy of the 1950s' multifunctionalism. Festive and casual clothes were no longer designed as separate products as the same items could fulfil different functions. The aim was to provide clothing for the entire nation, though Marimekko's products did not become people's clothing at the time, as the customers of the company were mainly educated and wealthy townspeople. Annika Rimala became the head designer of Marimekko in the period between the 1950s and 1960s, and developed the brand of Tasaraita in 1968. Tasaraita was a completely unique product, since the company had not produced jersey clothes before. Rimala's aim was to design a multifunctional jersey shirt that could be worn by anyone - from babies to old people, by 
men or women - the design concept clearly entailed the Maoist ideology of equality. Former consumers did not associate Tasaraita with Marimekko, since its sales remained rather modest. A year later Tasaraita was relaunched, but the ideological emphasis was dropped, and the sales of the product proved more successful. From the aspect of the clothing concept, this too was representative of the shaping of Marimekko's wholesome environment.

The apex of the idea of equality was the unisex clothing adopted at the beginning of the 1970s. The typical example of unisex fashion was an outfit of jeans and a T-shirt. For people, the changes in the standard of living and lifestyle meant transforming from a maker of clothes to a consumer. For Marimekko the changes stood for people's growing opportunities and willingness to choose Marimekko's clothes, and on the other hand, Tasaraita was in accordance with the renewed clothing practices and ideals. While before new items were designed for each season, the basic products, such as those of the Tasaraita brand, came to be on sale all the time, with only the colour scheme altering from one season to another. This popularisation of the basic products enabled the emergence of a line of classical clothing.

The success of the company in the $1970 \mathrm{~s}$, brought about by the success of Tasaraita product line, may be explained by Marimekko's clothing ideology being in accord with the general clothing ideology at the time.

The responses of interviewed informants clearly reveal that Tasaraita was by no means a "clothing item for the entire nation" as it has been advertised. Tasaraita's position as a political statement is also controversial. While the general opinion of older informants was that left radicalism and Marimekko were totally incompatible, the younger informants associated Tasaraita with the spirit of the 1960s and 1970s, and only one respondent clearly linked Marimekko and especially Tasaraita with political ideology.

Like jeans, Tasaraita has changed from the modern and even rebellious item of clothing to a widely worn item of casual clothing. Its increasing popularity, which started in the late $1960 \mathrm{~s}$, also attests to the topicality of the style associated with Tasaraita.

The article Marimekon Tasaraita pukeutumisilmiöna by Arja Turunen, written originally in Finnish, was published in 2004 in the e-journal of the Department of History and Ethnology of the Jyväskylä University, J@rgonia, no. 3 (available online at http://virtuaaliyliopisto.jyu.fi/jargon/jargonia/marimekko). 